\title{
Antioxidant activity and protective effects on oxidative DNA damage of Smilax china root
}

\author{
Tae-Won Jang ${ }^{2}$ (D) Chang-Gun Oh ${ }^{1} \cdot$ Jae-Ho Park ${ }^{1}$
}

토복령의 항산화 및 산화적 DNA 손상억제 활성

장태원 ${ }^{2} \cdot$ 오창근 $^{1} \cdot$ 박재호 $^{1}$

Received: 12 February 2018 / Accepted: 20 March 2018 / Published Online: 30 June 2018

(C) The Korean Society for Applied Biological Chemistry 2018

\begin{abstract}
Recently, cancer incidence in modern society is increasing sharply. DNA damage is caused by intrinsic or extrinsic factors in the human body, cells protect themselves by defense mechanism against DNA damage. Also, Aberrant DNA and deficient DNA repair are closely associated with various diseases, including aging and cancer. Researchers are interested in search for proper materials to inhibition for DNA damage. As knew the side effects of synthetic antioxidant, some researches have been conducted about cancer prevention materials derived from nature. Root of Smilax china, in Liliaceae, is used detoxification and tumor treatments traditionally. However, studies on the inhibitory effect of DNA damage haven't progressed. In this study, antioxidant activity and protective effects on oxidative DNA damage of $S$. china root were confirmed, relationship between those activities and contents of phenolic compounds in plants were established. S. china root effectively removed 1,1-diphenyl-2-picryl-hydrazyl radicals and 2,2'-azino-bis(3-ethylbenzothiazoline-6-sulphonic acid radicals.
\end{abstract}

Tae-Won Jang and Chang-Gun Oh are contributed equally.

Jae-Ho Park $(\bowtie)$

E-mail: parkjh@jwu.ac.kr

${ }^{1}$ Department of Medicinal Plant Science, Jungwon University, Goesan, 28024, Republic of Korea

${ }^{2}$ Department of Medicinal Plant Resources, Andong National University, Andong, 36729, Republic of Korea

This is an Open Access article distributed under the terms of the Creative Commons Attribution Non-Commercial License (http://creativecommons. org/licenses/by-nc/3.0/) which permits unrestricted non-commercial use, distribution, and reproduction in any medium, provided the original work is properly cited.
The quantification and identification of phenolic compounds were confirmed by high performance liquid chromatography analysis, its antioxidant activity was associated with some phenolic compounds. In addition, protective effects against hydroxyl radicals and ferrous ion-induced oxidative DNA damage were confirmed in plasmid DNA. In the cellular levels, S. china root suppressed the expression of $\gamma-\mathrm{H} 2 \mathrm{AX}$ and p53 protein in NIH 3T3. Besides, S. china root suppressed H2AX and p53 mRNA levels. In conclusion, $S$. china root had the effect on DNA protection and antioxidant.

Keywords Antioxidant $\cdot$ p53 $\cdot$ Phenolic compounds $\cdot$ Smilax china

\section{서 론}

현대사회의 암 발생률은 급격하게 증가하고 있으며, 세계 보건 기구(World Health Organization, WHO)에 따르면, 2012년까지 820 만 명 이상이 암 관련 질병으로 사망하였다고 밝혔다[1]. 이 와 더불어, 연구자들은 노화와 암 그리고 만성 질환 등과 같은 질병에 대한 예방 및 억제, 치료에 중점을 두고 있다. 특히 유 전적인 측면에서, 정상 세포가 종양 세포로 진행하는 과정은 개 시(initiation), 촉진(promotion), 진행(progression)의 과정을 거쳐 발생하며, 개시(initiation)는 전자 친화성 발암인자(initiator)가 생 체 내 대사에서 활성화되어, 유전자의 핵산에 비가역적으로 결 합하여 정상세포의 DNA를 손상시키고, 종양 전구세포 (preneoplastic cell)를 형성하는 돌연변이 현상이다. 암의 개시 (initiation)단계에서 발생하는 DNA 손상은 암 발생과 $83 \%$ 이 상의 높은 상관성을 나타내므로, 개시(initiation) 단계에서의 
DNA 손상 억제는 항암 활성에 있어서 중요한 역할을 한다[2,3] $\mathrm{DNA}$ 는 물리적, 화학적 자극에 의해 세포적 대사산물을 생성하 게 되며[4], 다양한 요인에 의해 활성산소종(reactive oxygen species, ROS)의 생성과 제거의 불균형이 발생한다[5]. 활성산소 종에 의한 세포 내 산화적 스트레스는 암, 염증 및 다양한 병 리적 현상에 잠재적인 인자로 작용한다[6]. 또한, 활성산소종은 산화적 스트레스로 유발되는 DNA 손상을 통해 발암 촉진 물 질로써 발암 작용에 중요한 역할을 하며[7], 활성산소종의 강한 반응성은 체내의 당, 지질, 단백질의 비가역적인 변형과 파괴를 유래한다[8]. DNA 손상은 세포 사멸과 직접적인 관계가 있으며 $[9,10], \mathrm{H} 2 \mathrm{AX}$ 는 DNA 손상 경로에서 가장 중요한 인자로 작용 한다[11,12]. 또한, 종양 억제 인자인 $\mathrm{p} 53$ 은 활성산소종에 대한 DNA 손상과 밀접하게 관계된 인자이다[13,14,15]. 그러므로, 활 성산소종의 경감은 매우 중요하며, 항산화제의 산화 억제 반응 은 체내에서 발생하는 라디칼로부터 인체를 보호하고, 활성산소 종에 의한 강한 산화 반응을 억제한다[16]. 이를 토대로 활성산 소종으로부터 인체를 보호할 수 있는 항산화제에 대한 연구가 활발히 진행되었으나, 합성 항산화제는 인체에 대한 다양한 부 작용과 독성 등 안정성 측면에서 문제가 되고 있다. 이와는 반 대로, 인체에 대한 유해성이 낮은 천연 항산화제의 사용이 증 대되고 있으며 $[17,18]$, 천연 항산화제로 사용될 수 있는 식물의 항산화 물질에 대한 연구가 주를 이루고 있다. 식물의 항산화 물질은 phenolic 화합물 및 flavonoid 계통의 화합물로 알려져 있으며[19], 이러한 물질들은 활성산소종과 화학적인 연쇄반응 을 통해 수소를 공여하는 반응을 한다[20]. 이전 연구에서 금속 이온에 대한 산화-환원 작용은 phenolic 화합물과 결합하거나 복합체를 형성하여 $\mathrm{H}_{2} \mathrm{O}_{2}$ 와 금속 이온과의 반응을 억제한다고 밝혔으며[21,22], Fenton 반응의 억제를 이끌어내어 $\mathrm{Fe}^{2+}$ 의 환원 반응을 일으키고, $\mathrm{OH}^{-}$를 직접적으로 제거하여 산화적 스트레스 로부터 DNA의 구조를 보호한다[23]. 토복령은 백합과(Liliacese) 에 속하는 활엽덩굴성 관목인 청미래덩굴 (Smilax china L.)의 근 경이며, 고뇨산혈증의 치유 및 신장보호 작용[24]이 있어 주로 통풍의 치료제[25]로 쓰인다. 토복령의 연구로는 해독[26], 항염, 항암 및 항산화 효과[25, 27]가 알려져 있다. 토복령이 나타내 는 다양한 생리활성은 phenolic 화합물인 kaempferol-7-O- $\beta$-Dglucoside [25], chlorogenic acid, caffeic acid, polydatin, resveratrol, astilbin, rutin 및 oxyresveratrol [24]에 근거하는 것으로 밝혀져 있다. 하지만 토복령의 DNA 손상에 대한 억제 효과에 대한 연 구는 미흡하다. 본 논문에서는 토복령의 항산화 효과 및 DNA 손상에 대한 억제효과를 확인하고, 식물이 포함하는 phenolic 화 합물의 활성과 연관 관계를 확인하고자 하였다.

\section{재료 및 방법}

\section{실험재료}

본 연구에 사용된 토복령(S. china L.)은 충청북도 괴산군 문광 면 탑골리 일대에서 채집하여 사용하였으며(voucher number: JWU-027), 중원대학교 생약자원개발학과의 이승현 교수가 동정 하였다. 본 연구에 사용된 High-performance liquid chromatography grade의 methanol, petroleum ether, ethyl acetate, chloroform, acetonitrile, dimethyl sulfoxide는 Merck (Frankfurter, Darmstadt,
Germany)제품을 사용하였다. 세포배양 및 실험을 위한 Dulbecco's modified Eagle's medium (DMEM), fetal bovine serum, penicillin/streptomycin, trypsin은 Hyclone (Logan, UT, USA) 제품을 사용하였다. 나머지 시약은 Sigma-Aldrich (St. Louis, $\mathrm{MO}, \mathrm{USA}$ ) 제품을 사용하였다. $\varphi \mathrm{X}-174 \mathrm{RF}$ I plasmid DNA는 Promega (Madison, WI, USA)에서 구입하여 사용하였다. 단백 질 전기영동을 위한 실험기기는 Bio-Rad Labs (Hercules, CA, USA) 제품을 사용하였으며, 모든 항체는 Abcam (Cambridge, MA, USA) 제품을 사용하였다. 표준품 및 모든 시약은 SigmaAldrich (St. Louis, MO, USA) 제품을 사용하였으며, 기타시약 및 기기는 별도 표기하였다.

\section{시료 추출 및 용매 분희}

토복령의 에틸아세테이트 분획물 $(2.6 \mathrm{~g})$ 은 건조시료 $300 \mathrm{~g}$ 을 분 쇄한 후, $80 \%$ 메탄올 $2.5 \mathrm{~L}$ 로 7일간 침지한 후 Whatman filter paper (GE Healthcare Life Sciences, Amersham Place, Little Chalfont, Buckinghamshire, England)로 여과하였다. 메탄 올 추출물을 $40^{\circ} \mathrm{C}$ 이하의 중탕에서 감압 환류 냉각장치 $(\mathrm{N}-$ $1110 \mathrm{~S}$, EYELA, Koishikawa, Japan)로 농축한 후 분별 깔때기 를 이용하여 페트롤리움 에테르, 에틸아세테이트 순으로 3회 용 매분획 하였다. 이 중 에틸아세테이트 분획물을 감압 환류 냉 각장치로 농축하여 실험 전까지 $-27^{\circ} \mathrm{C}$ 에 보관하였고, $\mathrm{DMSO}$ 에 $4000 \mathrm{ppm}$ 으로 용해하여 시료로 사용하였다. 항산화 활성을 나 타내는 성분들은 주로 phenolic 화합물로, 에탄올이나 에틸아세테 이트 등의 유기 용매 또는 수용성 에탄올 용액 등에 잘 녹는다.

\section{DPPH 라디칼 소거활성}

$\mathrm{DPPH}$ 를 이용한 전자 공여능은 Bondet 방법[28]을 참고하여 측 정하였다. $\mathrm{DPPH}$ solution은 $300 \mu \mathrm{M} \mathrm{DPPH}$ 를 $515 \mathrm{~nm}$ 에서 흡 광도 값이 1.00 이 되도록 에탄올을 이용하여 희석 준비하였다. 각 농도 별 추출물 $(0.32,1.6,8,40,200 \mu \mathrm{g} / \mathrm{mL}) 40 \mu \mathrm{L}$ 에 $\mathrm{DPPH}$ solution $760 \mu \mathrm{L}$ 를 첨가한 후 $37^{\circ} \mathrm{C}$ 에서 20 분 반응시켜 $\mathrm{UV} /$ Visible spectrophotometer (Human Cop, Xma-3000PC, Seoul, Korea) 를 이용하여 $515 \mathrm{~nm}$ 에서 흡광도를 측정하였다.

DPPH radical scavenging activity (\%)

$$
=\left[1-\left(\mathrm{A}_{\text {Sample }}-\mathrm{A}_{\text {Blank }}\right) / \mathrm{A}_{\text {Control }}\right] \times 100
$$

'A $\mathrm{A}_{\text {Sample }}$ '=Absorbance values of DPPH radicals after treatment with sample.

' $\mathrm{A}_{\text {Blank }}$ =Absorbance values of ethanol.

' $\mathrm{A}_{\text {Control }}=$ Absorbance values of DPPH radicals.

\section{ABTS 라디칼 소거활성}

2,2'-azino-bis(3-ethylbenzothiazoline-6-sulphonic acid (ABTS) 라디칼 소거 활성 능력은 Van den Berg 등의 방법[29]을 참고 하여 측정하였다. ABTS solution은 $7.4 \mathrm{mM} \mathrm{2,2'-Azinobis(3-}$ ethylbenzothiazoline-6-sulfonic acid) diammonium salt와 2.6 $\mathrm{mM}$ potassium persulfate를 혼합하여 24시간 ABTS radical을 형성시킨 후 증류수를 이용하여 $734 \mathrm{~nm}$ 에서 흡광도 값이 0.70 이 되도록 희석하였다. 각 농도 별 추출물 $40 \mu \mathrm{L}$ 에 $760 \mu \mathrm{L}$ 의 $\mathrm{ABTS}$ solution을 첨가한 후 $37^{\circ} \mathrm{C}$ 에서 20 분 반응시켜 $\mathrm{UV} /$ Visible spectrophotometer를 이용하여 $734 \mathrm{~nm}$ 에서 흡광도를 측 
정하였다.

ABTS radical scavenging activity (\%)

$$
=\left[1-\left(\mathrm{A}_{\text {Sample }}-\mathrm{A}_{\text {Blank }}\right) / \mathrm{A}_{\text {Control }}\right] \times 100
$$

'A $\mathrm{A}_{\text {Sample }}$ '=Absorbance values of ABTS radicals after treatment with sample.

' $\mathrm{A}_{\text {Blank }}$ '=Absorbance values of $\mathrm{H}_{2} \mathrm{O}$.

' $\mathrm{A}_{\text {Control }}=$ Absorbance values of ABTS radicals.

\section{Reducing Power}

Reducing power는 Oyaizu의 방법[30]을 참고하여 측정하였다. 각 농도 별 추출물 $100 \mu \mathrm{L}$ 에 $0.2 \mathrm{M}$ potassium phosphate buffer (pH 6.6) $250 \mu \mathrm{L}$ 과 $1 \%$ potassium hexacyanoferrate (III) $250 \mu \mathrm{L}$ 를 혼합한 후, $50^{\circ} \mathrm{C}$ 에서 20 분 반응시킨 후 찬물로 냉각 하여, trichloroacetic acid $250 \mu \mathrm{L}$ 를 첨가하였다. 위 반응액을 $2000 \mathrm{~g}$ 에서 5 분간 원심 분리하여 상등액 $400 \mu \mathrm{L}$ 에 증류수 400 $\mu \mathrm{L}$ 와 $0.10 \%$ ferric chloride $16 \mu \mathrm{L}$ 를 첨가하여 혼합한 후, $\mathrm{UV} /$ Visible spectrophotometer를 이용하여 $700 \mathrm{~nm}$ 에서 흡광도를 측 정하였다.

Reducing power (Relative value of $\mathrm{A}_{\text {Control, }} \%$ )

$$
=\left[\left(\mathrm{A}_{\text {Sample }}-\mathrm{A}_{\text {Blank }}\right) / \mathrm{A}_{\text {Control }}\right] \times 100
$$

'A $\mathrm{A}_{\text {Sample }}$ '=Absorbance values of Reducing power after treatment with sample.

'A $\mathrm{A}_{\text {Blank }}$ '=Absorbance values of $\mathrm{H}_{2} \mathrm{O}$.

' $\mathrm{A}_{\text {Control }}$ '=Absorbance values of Reducing power after treatment with L-ascorbic acid.

\section{Phenolic 화합물의 HPLC 분석}

Phenolic 화합물의 High performance liquid chromatography (HPLC) 분석은 SHIMADZU LC-20 HPLC system과 SHIMADZU SPD-M20A Diode Array Detector (DAD) (Kyoto, Japan)를 통해 분석하였다. 실험에 사용된 시료는 $1 \mathrm{mg}$ 을 취하여 $1 \mathrm{~mL}$ 의 메탄올에 용해하여 $0.45 \mu \mathrm{m}$ membrane filter (Waters, Milford, MA, USA)를 이용해 여과하였고, 시료 $10 \mu \mathrm{L}$ 를 메탄 올 및 $1 \%$ acetic acid $/ \mathrm{H}_{2} \mathrm{O}$ 을 이동상으로 SHIMADZU Shimpack GIS column $(4.6 \times 250 \mathrm{~mm})$ packed with $5.0 \mu \mathrm{m}$ diameter particles를 이용하여 흡광도 $280 \mathrm{~nm}$ 에서 분석하였다. 추출물의 각 phenolic 화합물은 각각의 표준품과 비교하여 동정 및 정량 하였다.

$\varphi$ X-174 RF I plasmid DNA 산화적 스트레스 손상 억제 활성 $\varphi \mathrm{X}-174 \mathrm{RF}$ I plasmid DNA 산화적 스트레스 손상 억제 활성 은 Jung과 Surh의 방법[31]을 참고하여 측정 하였다. Ferric chloride $\left(\mathrm{FeCl}_{2}\right)$ 를 통한 산화적 스트레스는 각 농도 별 추출물 $40 \mu \mathrm{L}$ 와 $4.5 \mathrm{mM} \mathrm{FeCl}{ }_{2} 60 \mu \mathrm{L}$ 와 증류수 $700 \mu \mathrm{L}$ 를 넣은 후, $37^{\circ} \mathrm{C}$ 에서 15 분 반응하였다. 반응물 $20 \mu \mathrm{L}$ 와 $\varphi \mathrm{X}-174 \mathrm{RF} \mathrm{I}$ plasmid DNA $5 \mu \mathrm{L}$ 를 넣고, $37^{\circ} \mathrm{C}$ 에서 3 분간 반응한 후, $10 \mathrm{X}$ loading buffer와 혼합한 후 $1 \%$ agarose gel로 전기 영동을 실 시한 후 $\mathrm{UV}$ 하에서 사진 촬영하였다. Ferrous sulfate $\left(\mathrm{FeSO}_{4}\right)$ 을 통한 산화적 스트레스는 각 농도 별 추출물 $40 \mu \mathrm{L}$ 와 $1.5 \mathrm{mM}$ $\mathrm{FeSO}_{4}$ 와 $1.5 \mathrm{mM}$ hydrogen peroxide $\left(\mathrm{H}_{2} \mathrm{O}_{2}\right)$ 를 $1: 1$ 로 혼합한
용액을 $760 \mu \mathrm{L}$ 를 첨가한 뒤 $37^{\circ} \mathrm{C}$ 에서 15 분간 반응하였다. 반응 물 $20 \mu \mathrm{L}$ 와 $\varphi \mathrm{X}-174 \mathrm{RF}$ I plasmid DNA $5 \mu \mathrm{L}$ 를 넣고, $37^{\circ} \mathrm{C}$ 에서 3 분간 반응한 후, $10 \mathrm{X}$ loading buffer와 혼합한 후 $1 \%$ agarose gel로 전기영동을 실시한 후 UV하에서 사진 촬영하였다.

\section{세포배양}

본 연구에 사용된 NIH 3T3 세포는 American Type Culture Collection (ATCC, Manassas, VA, USA)에서 분양 받아 실험 하였다. 세포는 $1 \%$ penicillin/streptomycin 및 $10 \%$ fetal bovine serum이 포함된 $\mathrm{DMEM}$ 에서 $37^{\circ} \mathrm{C}, 5 \% \mathrm{CO}_{2}$ 조건하에 배양하였다.

\section{세포 생존율}

$\mathrm{NIH} 3 \mathrm{~T} 3$ 세포를 96-well plate에 $1.0 \times 10^{4}$ cells/well의 밀도로 분주하여, 24시간 배양한 후 농도 별로 시료를 처리하였다. 시 료 처리 24시간 후 alamar Blue ${ }^{\circledR}$ Cell Viability Reagent (Thermo Fisher Scientific, Waltham, MA, USA)을 배지의 총 량의 $10 \%$ 씩 처리하여 2시간 배양하였다. 반응 후 UV/Visible spectrophotometer (Human Cop, Seoul, Korea)로 $570 \mathrm{~nm}$ 에서 흡광도를 측정하여 세포생존율을 확인하였다.

\section{Immunoblotting}

$\mathrm{NIH} 3 \mathrm{~T} 3$ 세포를 6-well plate에 $1.0 \times 10^{5}$ cells/well의 밀도로 분 주하여, 24시간 배양한 후 농도 별로 시료 및 LPS를 처리하였 다. 시료 처리 24시간 후 $\mathrm{PBS}$ 로 두 번 세척한 후, protease inhibitor cocktail을 포함한 RIPA buffer로 용해한 후 얼음에서 30 분간 정치시켰다. 세포 용해액을 $4^{\circ} \mathrm{C}, 12,000 \mathrm{rpm}$ 에서 20 분 간 원심분리하고, 상층액은 Bradford 시약(Bio-rad)을 이용하여 단백질 정량을 실시하였다. 세포 용해액은 $2 \times$ Lamilae buffer와 혼합하여 $95^{\circ} \mathrm{C}$ 에서 5 분간 가열 후 각 $20 \mu \mathrm{g}$ 단백질량에 해당 하는 시료를 $10 \% \mathrm{SDS}-\mathrm{PAGE}$ 에서 전기 영동하여 분리하였다. 전기 영동된 단백질은 polyvinylidene difluoride membrane 막 에 옮겨 상온에서 1 시간 동안 blocking $(5 \%$ skim milk in TBST) 하였다. 1 차 항체를 $1: 2000$ 으로 희석하여 $4^{\circ} \mathrm{C}$ 에서 overnight 처리하였다. 이후 10 분 간격으로 TBST로 3 회 세척하고 , 2차 항체 1:5000으로 희석하여 1시간 동안 반응시켰다. 이후 10 분 간격으로 TBST로 3회 세척하고 enhanced chemiluminescence western blotting detection kit (Bio-rad)로 반응하였다. 단백질 밴드는 FluorChem E (Cell biosciences, Palo Alto, CA, USA)로 촬영하여 확인하였다.

\section{Total RNA 추출 및 cDNA 합성}

$\mathrm{NIH} 3 \mathrm{~T} 3$ 세포를 6-well plate에 $1.0 \times 10^{5}$ cells/well로 분주하여, 24 시간 배양한 후 농도 별로 시료를 처리했다. 시료 처리 48시 간 후 PBS로 두 번 세척한 후, Nucleo $\mathrm{Spin}^{\circledR}$ RNA Plus (Macherey-Nagel, Duren, Germany)를 이용하여 total RNA를 얻었다. 모든 과정은 $4^{\circ} \mathrm{C}$ 에서 진행되었으며, Quantus fluorometer RNA system (Promega)를 사용하여 정량하였으며, cDNA 합성 을 위해 $1 \mu \mathrm{g}$ 의 total RNA를 사용하여 reverse transcription kit (ReverTra Ace - $\alpha$-, Toyobo, Osaka, Japan)를 이용하여 $\mathrm{cDNA}$ 를 합성하였다. 


\section{RT-PCR}

cDNA상의 타겟 유전자를 증폭시키기 위하여 Quick Taq ${ }^{\circledR} \mathrm{HS}$ Dye Mix (Toyobo)와 합성한 cDNA, forward primer와 reverse primer로 $\mathrm{PCR}$ 을 수행하였다. $\mathrm{PCR}$ 의 조건은 다음과 같다. $94^{\circ} \mathrm{C}$ 로 2 분 간 denaturation을 시킨 후, $94^{\circ} \mathrm{C}$ 에서 30 초 간 denaturation 후 $55^{\circ} \mathrm{C}$ 에서 30 초 간 annealing, $68^{\circ} \mathrm{C}$ 에서 1 분 간 extension을 25 cycle 반복하였고 마지막 단계로 $72^{\circ} \mathrm{C}$ 에서 10 분 간 extension하 였다. House keeping gene으로 $\beta$-actin을 사용하였고 2\% agarose gel (Affymetrix, Cleveland, $\mathrm{OH}, \mathrm{USA}$ )로 UV 상에서 band를 확인하였다. 각 primer의 서열은 다음과 같다.

H2AX forward 5'-TTG CTT CAG CTT GGT GCT TAG3', reverse 5'-AAC TGG TAT GAG GCC AGC AAC-3', p53 forward 5'-CGG ATA GTA TTT CAC CCT CAA GAT CCG-3', reverse 5'-AGC CCT GCT GTC TCC AGA CTC3', GADPH forward 5'-AAC TTT GGC ATT GTG GAA GG-3', reverse 5'-ATG CAG GGA TGA TGT TCT GG-3'

\section{통계학적 분석}

모든 실험 결과는 3 번 이상 수행하였으며, 통계분석은 SPSS 18.0 (Statistical Package for the Social Sciences)을 이용하여 각 실험의 평균과 표준편차를 계산하였고, one-way analysis of variance (ANOVA)로 분석하였다. 그룹 간 비교는 Student's ttest를 통해, $p>0.05$ 수준에서 *로 표기하였다.

\section{결 과}

\section{항산화 활성}

토복령의 항산화 활성을 확인하기 위해 $\mathrm{DPPH}$ 라디칼 및 ABTS 라디칼에 대한 소거 활성을 확인하였으며 reducing power를 평가하였다. 토복령의 DPPH 라디칼 소거활성을 확인 한 결과(Fig. 1), 추출물 농도 $0.32,1.6,8,40,200 \mu \mathrm{g} / \mathrm{mL}$ 에서 각각 $1.6 \pm 0.7,11.6 \pm 0.9,38.3 \pm 3.0,78.7 \pm 0.8,83.3 \pm 1.0 \%$ 로 나타 났다. 강력한 항산화제로 알려져 있는 L-ascorbic acid [32]를 대조군으로 하였으며, 같은 농도에서 각각 $5.3 \pm 0.5,20.9 \pm 0.0$,

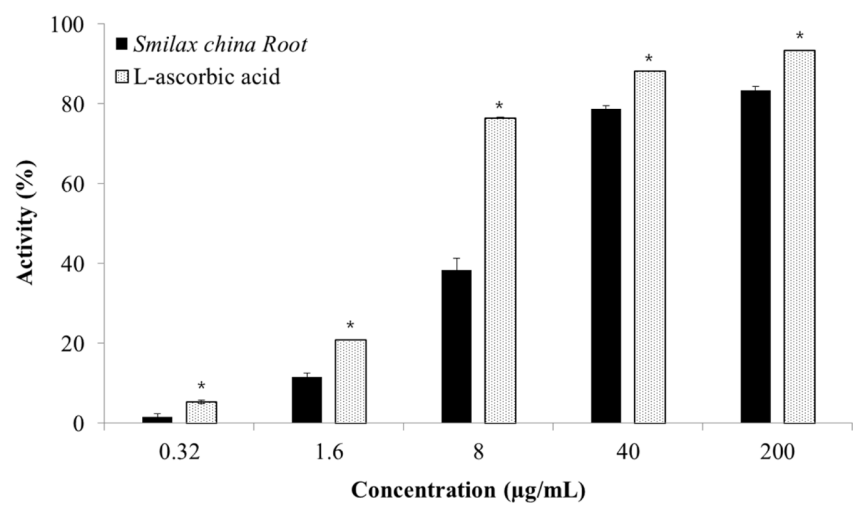

Fig. 1 DPPH radical scavenging activity (\%) of Smilax china Root. Values are expressed as means $\pm \mathrm{SD}$ of three independent experiments. $p<0.05$ as compared with the same concentration of L-ascorbic acid respectively

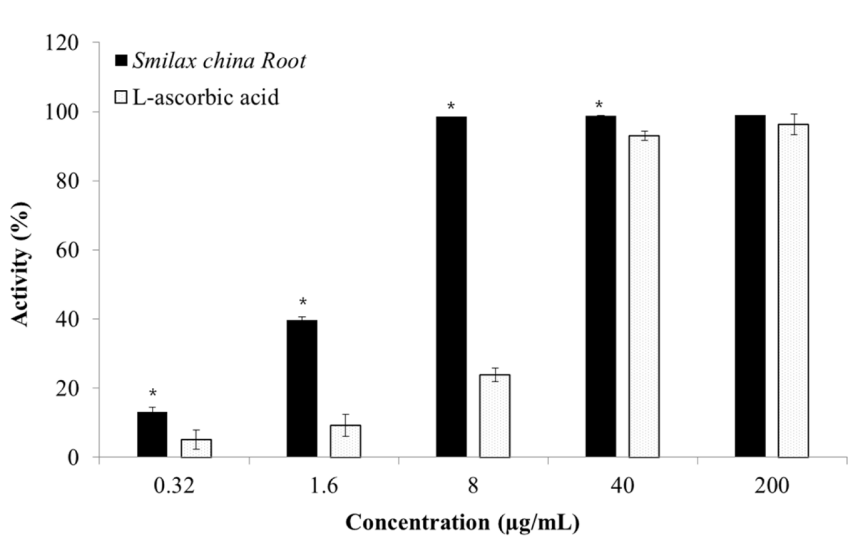

Fig. 2 ABTS radical scavenging activity (\%) of Smilax china Root. Values are expressed as means $\pm \mathrm{SD}$ of three independent experiments. $p<0.05$ as compared with the same concentration of L-ascorbic acid respectively

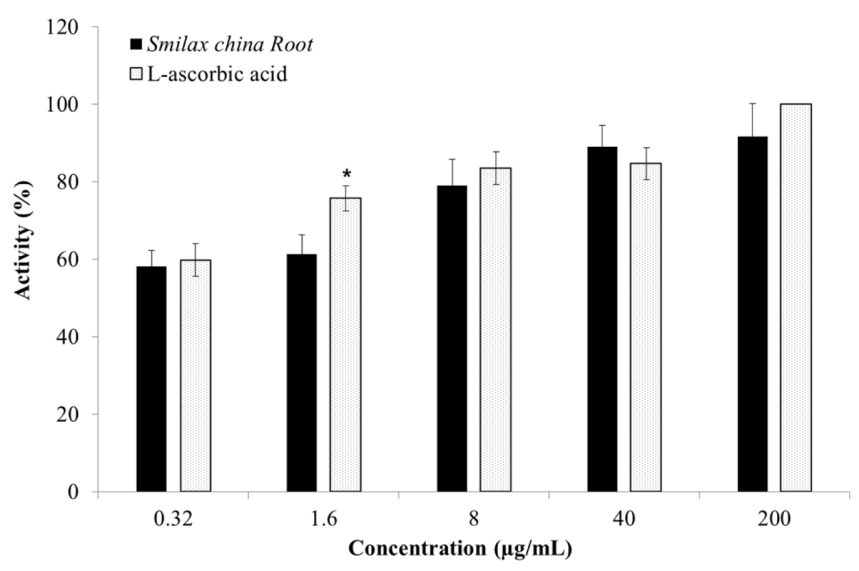

Fig. 3 Reducing power (\% of control) of Smilax china Root. Values are expressed as means $\pm \mathrm{SD}$ of three independent experiments. $p<0.05$ as compared with the same concentration of L-ascorbic acid respectively

$76.5 \pm 0.1,88.2 \pm 0.0,93.5 \pm 0.1 \%$ 로 나타났다. 모든 농도에서 $\mathrm{L}-$ ascorbic acid의 DPPH 라디칼 소거 활성이 높게 나타났지만, 추 출물 농도 $200 \mu \mathrm{g} / \mathrm{mL}$ 에서 $83.3 \pm 0.1 \%$ 의 $\mathrm{DPPH}$ 라디칼 소거 활 성이 확인되었다. 토복령의 $\mathrm{ABTS}$ 라디칼 소거활성을 확인한 결과(Fig. 2), 추출물 농도 $0.32,1.6,8,40,200 \mu \mathrm{g} / \mathrm{mL}$ 에서 각 각 $13.2 \pm 1.2 \%, 39.8 \pm 0.8 \%, 98.5 \pm 0.0 \%, 98.8 \pm 0.0 \%, 99.0 \pm 0.0 \%$ 로 나타났다. L-Ascorbic acid를 대조군으로 하였으며, 같은 농 도에서 각각 $5.1 \pm 2.7,9.3 \pm 3.2,23.9 \pm 1.9,93.0 \pm 1.3,96.3 \pm 2.9 \%$ 로 나타났다. 모든 농도에서 토복령의 ABTS 라디칼 소거 활성 이 대조군보다 통계적으로 유의성이 있었으며, 특히 추출물 농 도 $8 \mu \mathrm{g} / \mathrm{mL}$ 에서 뛰어난 $\mathrm{ABTS}$ 라디칼 소거 활성을 나타냈다. Reducing power는 대조군인 L-ascorbic acid 처리 농도 200 $\mu \mathrm{g} / \mathrm{mL}$ 을 $100 \%$ 로 하여 비교 분석하였다. 토복령의 Reducing power를 평가한 결과(Fig. 3), 추출물 농도 $0.32,1.6,8,40$, $200 \mu \mathrm{g} / \mathrm{mL}$ 에서 각각 $58.1 \pm 4.1,61.4 \pm 5.1,79.1 \pm 6.8,89.1 \pm 5.5$, $91.8 \pm 8.5 \%$ 로 나타났다. L-Ascorbic acid를 대조군으로 하였으며, 같은 농도에서 각각 $59.9 \pm 4.2,75.8 \pm 3.2,83.5 \pm 4.2,84.7 \pm 4.1$, $100.0 \pm 0.0 \%$ 로 나타났다. 모든 농도에서 토복령과 대조군의 

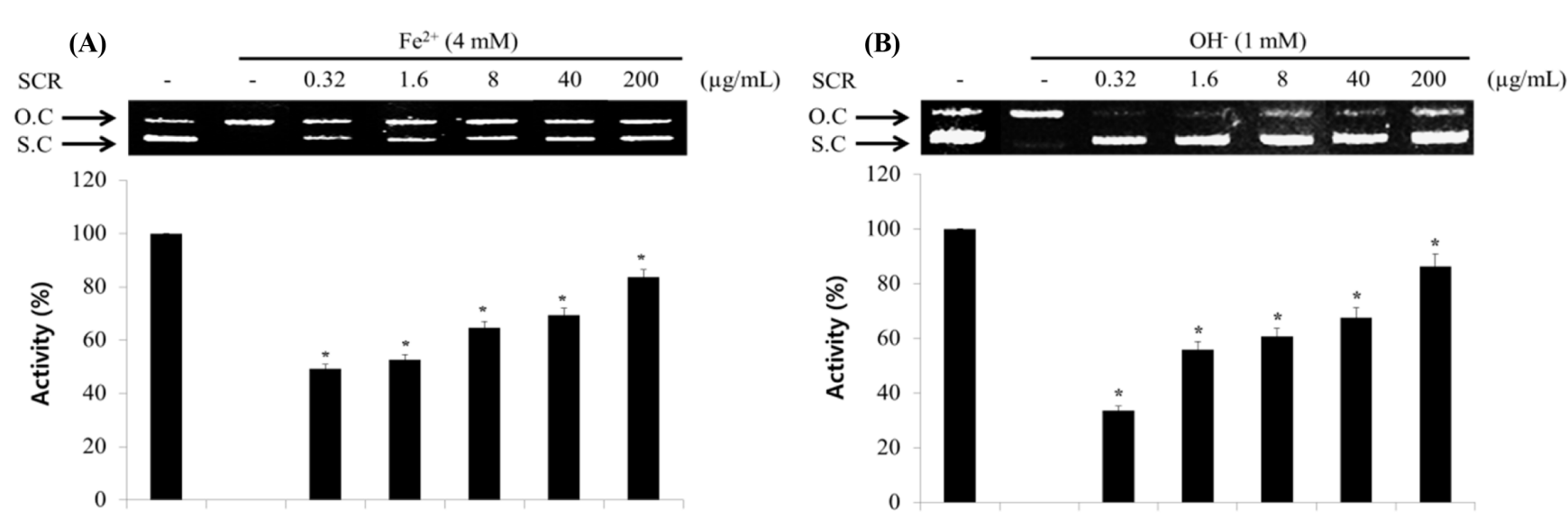

Fig. 4 Protective effects of Smilax china Root (SCR) on oxidative DNA damage by $\varphi$ X-174 RF I plasmid DNA. $\varphi$ X-174 RF I plasmid DNA Plasmid DNA was treated with various concentrations $(0,0.32,1.6,8,40$ and $200 \mu \mathrm{g} / \mathrm{mL})$ of SCR and oxidative damage by Fe ${ }^{2+}$ ion or hydroxyl radicals. Values are expressed as means \pm SD of three independent experiments. $p<0.05$ as compared with the non-treated control group. Protective effect of SCR against oxidative DNA damage in a dose-dependent manner \% remaining supercoiled form against oxidative DNA cleavage\% remaining supercoiled form was quantified using the software Un-SCAN-IT gel Version 5.1 (Silk Scientific, Inc., Orem, Utah, USA). Fe ${ }^{2+}$ : $\mathrm{mM}_{\mathrm{FeCl}}$, OH: 1 $\mathrm{mM} \mathrm{FeSO}_{4}+1 \mathrm{mM} \mathrm{H}_{2} \mathrm{O}_{2}$, O.C: Open circular, S.C: Super-coiled

reducing power는 통계적으로 유의성이 없었다.

\section{산화적 스트레스로 유발된 DNA 손상에 대한 방어 효과} 토복령의 산화적 스트레스에 의한 DNA 손상 억제 활성을 평 가하기 위해 $\mathrm{FeCl}_{2}$ 및 $\mathrm{FeSO}_{4}$ 와 $\mathrm{H}_{2} \mathrm{O}_{2}$ 의 Fenton 반응을 이용한 산화적 스트레스를 이용하여 $\varphi \mathrm{X}-174 \mathrm{RF}$ I plasmid DNA의 손 상을 유발하였으며, $\varphi \mathrm{X}-174 \mathrm{RF}$ I plasmid DNA cleavage assay를 이용한 비세포적 시스템으로 평가하였다. $\mathrm{FeCl}_{2}$ 로 유발 한 산화적 스트레스에 대한 토복령의 DNA 손상 억제 활성을 확인한 결과(Fig. 4A), 산화적 스트레스에 의한 손상을 받은 $\mathrm{DNA}$ 는 open-circular $(\mathrm{OC})$ 형태로 전환되었다. 시료를 처리한 모든 농도에서 산화적 스트레스에 의한 DNA 손상을 억제하는 활성을 보였다. $\mathrm{OH}^{-}$에 의해 유발된 산화적 스트레스에 대한 토 복령의 DNA 손상 억제 활성을 확인한 결과(Fig. 4B), 산화적 스트레스에 의한 손상을 받은 $\mathrm{DNA}$ 는 $\mathrm{OC}$ 형태로 전환되었으 며, 시료를 처리한 모든 농도에서 산화적 스트레스에 의한 DNA 손상을 억제하는 활성을 보였다.

\section{HPLC-UV를 통한 phenolic 화합물 분석}

토복령의 phenolic 화합물의 함량 및 동정은 HPLC 및 UV detector를 통해 분석하였다. phenolic 화합물의 함량 분석 및 동 정 결과(Fig. 5), chlorogenic acid, epicatechin을 동정하였으며, 각 표준품에 의한 정량직선방정식을 통해 함량을 분석한 결과, 각각 $8.3,5.9 \mathrm{mg} / \mathrm{g}$ 으로 나타났으며, caffeic acid는 검출 되지 않았다(Table 1).

\section{NIH 3T3에 대한 세포 독성}

토복령의 NIH 3T3 세포에 대한 세포 독성을 확인하기 위해 세 포 독성 실험을 실시하였다. 토복령 추출물 농도 $25,50,100$, $200400 \mu \mathrm{g} / \mathrm{mL}$ 에서 각각 $108.2 \pm 10.7,143.0 \pm 25.8,142.8 \pm 8.5$, $154.3 \pm 14.5,155.0 \pm 10.6 \%$ 로 $\mathrm{NIH} 3 \mathrm{~T} 3$ 세포에 대한 독성이 나
타나지 않았다(Fig. 6).

\section{세포 내 $\gamma$-H2AX 및 p53 억제 효과}

산화적 스트레스로 유발된 NIH 3T3 세포의 DNA 손상에 대한 토복령의 억제 효과를 확인하기 위해 $\gamma-\mathrm{H} 2 \mathrm{AX}$ 단백질 발현을 확인한 결과(Fig. 7A), 산화적 스트레스에 의해 증가된 $\gamma-\mathrm{H} 2 \mathrm{AX}$ 의 발현양 $(131.2 \pm 7.8 \%)$ 은 농도 의존적으로 토복령 추출물에 의 해 저해되었다. 농도 의존적으로 토복령 추출물에 의해 $\gamma-\mathrm{H} 2 \mathrm{AX}$ 단백질 발현이 저해되었으며, 시료 농도 $25,50,100 \mu \mathrm{g} / \mathrm{mL}$ 에 서 각각 $112.1 \pm 6.7,58.1 \pm 3.4,32.5 \pm 1.9 \%$ 의 발현을 나타냈다. $100 \mu \mathrm{g} / \mathrm{mL}$ 의 L-ascorbic acid (77.11 $\pm 4.6 \%)$ 와 비교하였을 때, 같은 농도 및 $50 \mu \mathrm{g} / \mathrm{mL}$ 농도에서도 토복령의 발현 억제 효과 가 높았다. p53 단백질 발현을 확인한 결과(Fig. 7B), 산화적 스트레스에 의해 증가된 $\mathrm{p} 53$ 의 발현양 $(150.4 \pm 8.3 \%)$ 은 농도 의 존적으로 토복령 추출물에 의해 저해되었다. 농도 의존적으로 토복령 추출물에 의해 p53 단백질 발현이 저해되었으며, 시료 농도 $25,50,100 \mu \mathrm{g} / \mathrm{mL}$ 에서 각각 $133.0 \pm 7.3,111.2 \pm 6.1$, $67.8 \pm 3.7 \%$ 의 발현을 나타냈다. $100 \mu \mathrm{g} / \mathrm{mL}$ 의 L-ascorbic acid $(80.3 \pm 4.4 \%)$ 와 비교하였을 때, 같은 농도에서의 토복령의 발현 억제 효과가 높았다. 산화적 스트레스로 유발된 NIH $3 \mathrm{~T} 3$ 세포 의 DNA 손상에 대한 토복령의 억제 효과를 확인하기 위해 $\mathrm{H} 2 \mathrm{AX}$ mRNA 수준을 확인한 결과(Fig. 8A), 산화적 스트레스 에 의해 증가된 $\mathrm{H} 2 \mathrm{AX}$ mRNA 수준(131.2 $\pm 7.8 \%)$ 은 농도 의존 적으로 토복령 추출물에 의해 저해되었다. 농도 의존적으로 토 복령 추출물에 의해 $\mathrm{H} 2 \mathrm{AX} \mathrm{mRNA}$ 수준이 저해되었으며, 50 , $100 \mu \mathrm{g} / \mathrm{mL}$ 농도에서도 토복령의 발현 억제 효과가 높았다. p53 mRNA 수준을 확인한 결과(Fig. 8B), 산화적 스트레스에 의해 증가된 p53 mRNA 수준은 농도 의존적으로 토복령 추출물에 의해 저해되었다. $50,100 \mu \mathrm{g} / \mathrm{mL}$ 농도에서도 토복령의 발현 억 제 효과가 높았다. 

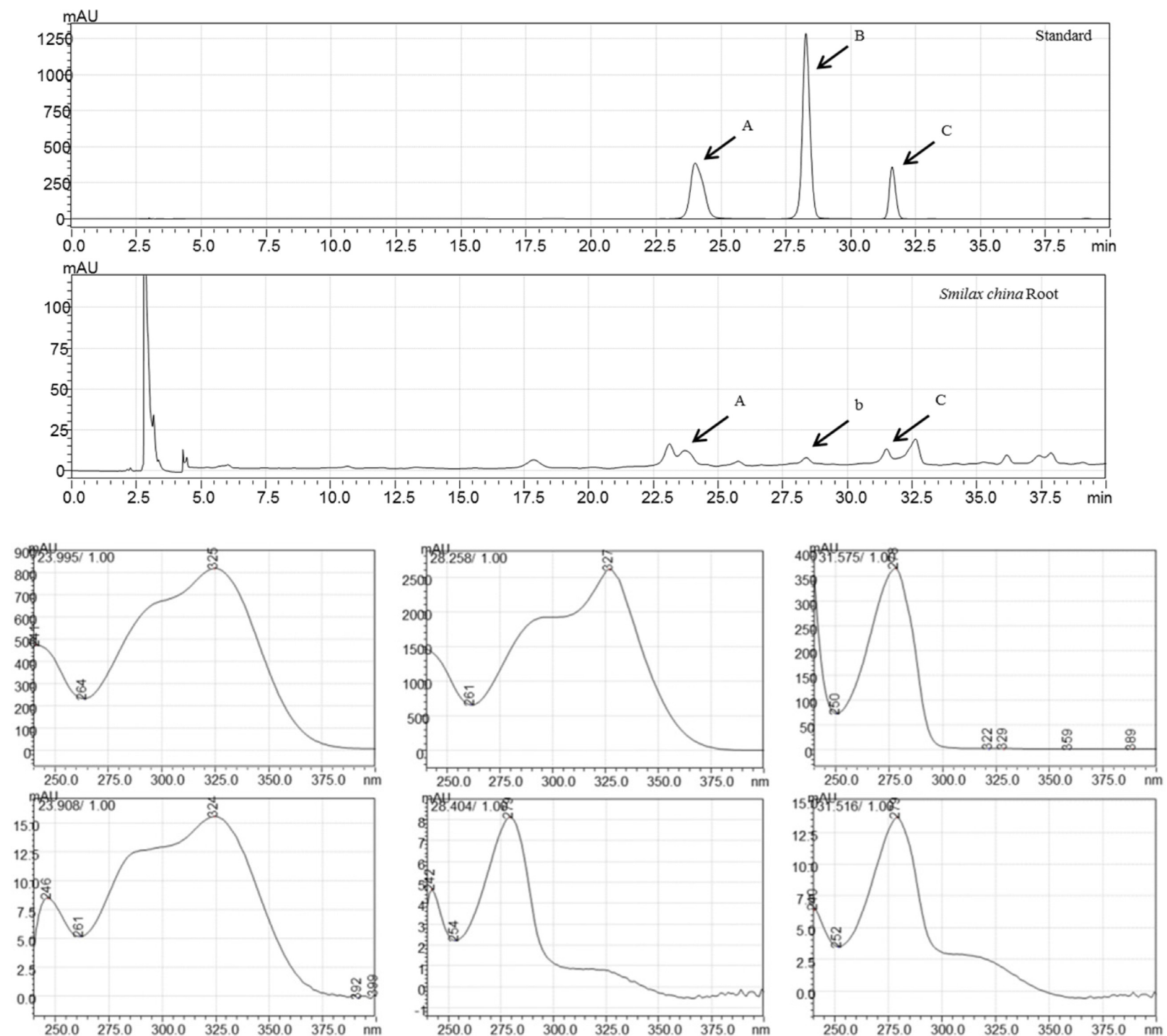

Fig. 5 Chromatogram of Smilax china Root in the identification by High performance liquid chromatography (HPLC). Column: Shim-pack GIS $(250 \times 4.6 \mathrm{~mm}, 5 \mu \mathrm{m})$, Mobile phase: acetonitrile and $1 \%$ acetic acid/ $\mathrm{H}_{2} \mathrm{O}\left(0-10 \mathrm{~min}, 92 \% 1 \%\right.$ acetic acid/ $\mathrm{H}_{2} \mathrm{O}$ to $10-40 \mathrm{~min} 80 \% 1 \% \mathrm{acetic}$ acid/ $\left.\mathrm{H}_{2} \mathrm{O}\right)$, Flow-rate: $1.0 \mathrm{~mL} / \mathrm{min}$, Injection volume: $10 \mu \mathrm{L}$, monitored at $280 \mathrm{~nm}$. A: Chlorogenic acid, B: caffeic acid, b: Unknown, C: epicatechin

Table 1 Quantification of phenolic compounds of Smilax china Root

\begin{tabular}{cccc}
\hline \hline Sample & $\begin{array}{c}\text { Chlorogenic acid } \\
(\mathrm{mg} / \mathrm{g})\end{array}$ & $\begin{array}{c}\text { Caffeic acid } \\
(\mathrm{mg} / \mathrm{g})\end{array}$ & $\begin{array}{c}\text { Epicatechin } \\
(\mathrm{mg} / \mathrm{g})\end{array}$ \\
\hline Smilax china Root & 8.3 & Not detected & 5.9 \\
\hline
\end{tabular}

\section{고 찰}

본 연구는 고뇨산혈증과 해독 등에 사용되어온 토복령의 항산 화 활성, 산화적 DNA 손상 억제 활성 및 phenolic 화합물의 동정 및 함량 분석을 통해 생물학적 유용성을 검증하였다. superoxide와 hydroxyl radical 등과 같은 활성산소종은 생체 내 거대분자들에 치명적인 영향을 미치고, 산화적 스트레스를 유발 하므로 살아있는 유기체는 산화적 스트레스에 대항하여 자기방
어를 위한 기작을 작동한다[33]. 토복령의 $\mathrm{DPPH}$ 라디칼 소거 활성에서, 추출물 농도에 따라 농도 의존적인 효과를 나타내었 으며, L-ascorbic acid $\left(5.07 \mu \mathrm{g} / \mathrm{mL}\right.$ )와 비교하여 $\mathrm{IC}_{50}$ (inhibitory concentration) 값이 $13.32 \mu \mathrm{g} / \mathrm{mL}$ 로 나타났다. 이전 연구에서 청 미래덩쿨의 잎 에틸아세테이트 추출물의 $\mathrm{IC}_{50}$ 값 $(2.66 \pm 0.03 \mathrm{mg} /$ $\mathrm{mL}$ )과 비교하여[34], 상당한 DPPH 라디칼 소거 활성을 나타냈 다. $\mathrm{ABTS}$ 와 $\mathrm{DPPH}$ 는 같은 라디칼이지만 $\mathrm{DPPH}$ 는 자유라디칼 이며 $\mathrm{ABTS}$ 는 cation 라디칼이다. 이에 따른 각 라디칼과 항산 화물질 사이의 반응에 차이가 있다[35]. ABTS 라디칼 소거 활 성에서, L-ascorbic acid $(10.49 \mu \mathrm{g} / \mathrm{mL})$ 와 비교하여 $\mathrm{IC}_{50}$ 값이 $1.57 \mu \mathrm{g} / \mathrm{mL}$ )로 매우 높은 $\mathrm{ABTS}$ 소거 활성을 보였다. 토복령은 $\mathrm{DPPH}$ 에서 기인하는 자유라디칼에 대한 소거활성에 비해 $\mathrm{ABTS}$ 에서 유래하는 cation 라디칼을 효과적으로 소거하였다. 항산화 제와 같은 환원제는 $\mathrm{Fe}^{3+} /$ ferricyanide complex를 환원시켜 


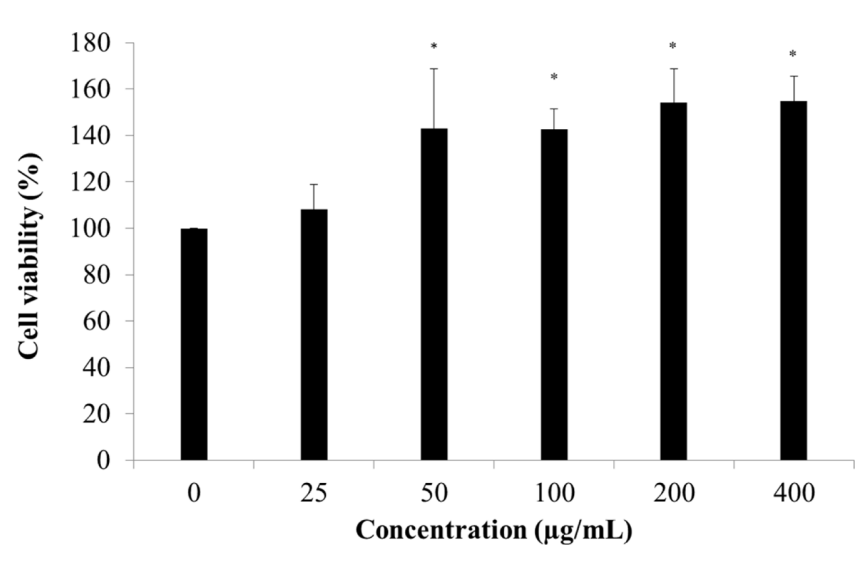

Fig. 6 Effect of Smilax china Root on cell viability. NIH 3T3 cells were incubated with various concentrations of Smilax china Root (0-400 $\mu \mathrm{g})$ $\mathrm{mL}$ ) for $24 \mathrm{~h}$. Cell viability was determined by alamar blue reagents. Value was then expressed to non-treated control group, which was set as $100 \%$. Results are expressed as mean \pm SD for each group from three independent experiments. $p<0.05$ as compared with the non-treated (NT) control group. Each band was quantified using the software Un-SCANIT gel Version 5.1(Silk Scientific, Inc., Orem, Utah, USA)

ferrous 형태로 전환하고, 이 과정을 통해 형성된 Perl's Prussian blue의 흡광도는 환원력을 평가하는 지표로 사용된다[36]. 토복 령의 환원력은 L-ascorbic acid와 유의성 없는 환원력을 나타내 었다. 높은 항산화 효과와 환원력은 노화 및 성인병을 포함하 는 다양한 질병의 원인인 활성산소종을 억제한다[37,38]. 토복 령의 phenolic 화합물 및 다양한 phytochemical의 생리 활성 [24,25]을 참고하여, chlorogenic acid, caffeic acid, epicatechin 의 HPLC 분석을 통한 phenolic 화합물을 동정한 결과, chlorogenic acid, epicatechin이 확인되었다. 식물에서 확인되는 phenolic 화합물의 항산화 활성은 그 구조적인 특징과 관련성이
높은데, 이들은 금속 킬레이트제, 환원제, 활성산소의 소거제, 사슬전단 항산화제(chain breaking antioxidants)로 작용하는 것 으로 알려져 있다. 또한, phenolic 화합물은 항산화 활성뿐만 아 니라 항암 및 항균 작용을 포함하는 다양한 생리 활성을 나타 내는 물질로 알려져 있다[39] 토복령의 $\mathrm{DPPH}, \mathrm{ABTS}$ 라디칼 소거 활성 및 환원력은 chlorogenic acid 및 epicatechin 등과 같은 phenolic 화합물과 깊은 연관성이 있다고 사료된다. 정상 적인 plasmid DNA는 supercoiled 형태로 존재하나 $\mathrm{H}_{2} \mathrm{O}_{2}$ 와 철 의 Fenton 반응에 의해 생성된 $\mathrm{OH}^{-}$라디칼 또는 $\mathrm{Fe}^{2+}$ 존재 하 에서는 산화적 스트레스에 의한 손상을 받아 $\mathrm{OC}$ 형태로 전환된 다. 토복령은 $\mathrm{FeCl}_{2}$ 에서 기인한 $\mathrm{Fe}^{2+}$ 에 의한 산화적 손상 및 $\mathrm{FeSO}_{4}$ 에서 기인한 $\mathrm{OH}^{-}$산화적 손상 모두에 억제 효과를 나타 냈다. 특히 $\mathrm{FeCl}_{2}$ 에서 기인한 $\mathrm{Fe}^{2+}$ 에 대한 강한 억제 효과를 보 였다. 이를 통해 $\mathrm{OH}^{-}$라디칼에 비해 금속 킬레이팅 작용이 비 교적 효과적인 것을 확인하였다. 또한, 산화적 스트레스는 알킬 기를 DNA 염기로 공유결합시켜 DNA 이중 나선 구조의 손상 과 DNA 가닥의 파괴를 유도하는데[40], DNA 이중 가닥의 손 상은 돌연변이, 염색체 이상 및 세포 죽음에 이르게 하는 가장 치명적인 원인이다[41,42]. 산화적 스트레스는 또한 telangiectasiamutated (ATM)와 ATM-Rad3-related (ATR) kinases의 인산화 를 유도하여 DNA 이중 구조 손상 과정을 진행시킨다[43]. $\mathrm{ATM} / \mathrm{ATR}$ 의 인산화는 $\mathrm{DNA}$ 구조의 손상과 관련이 깊은 cell cycle check point kinases (Chk2/Chk1), 종양 억제 인자 p53, 인산화 된 histone $\gamma-\mathrm{H} 2 \mathrm{AX}$ foci의 발현을 조절한다[44]. DNA damage check point 1 매개체인 $\gamma-\mathrm{H} 2 \mathrm{AX}$ 는 DNA 손상 복구 인자들을 결집하고 DNA 복구를 진행하므로[45], DNA 손상에 대한 지표로 사용된다. 토복령은 $\gamma-\mathrm{H} 2 \mathrm{AX}$ 및 $\mathrm{p} 53$ 의 단백질 발 현을 세포 수준에서 저해하였으며, 농도 의존적인 저해 효과를 나타냈다. H2AX 및 p53 mRNA 수준의 저해 효과는 토복령의 DNA 손상 억제 효과가 단백질 발현뿐만 아니라 mRNA 수준 도 효과적으로 저해한다는 것을 나타낸다. 결론적으로, phenolic
(A)

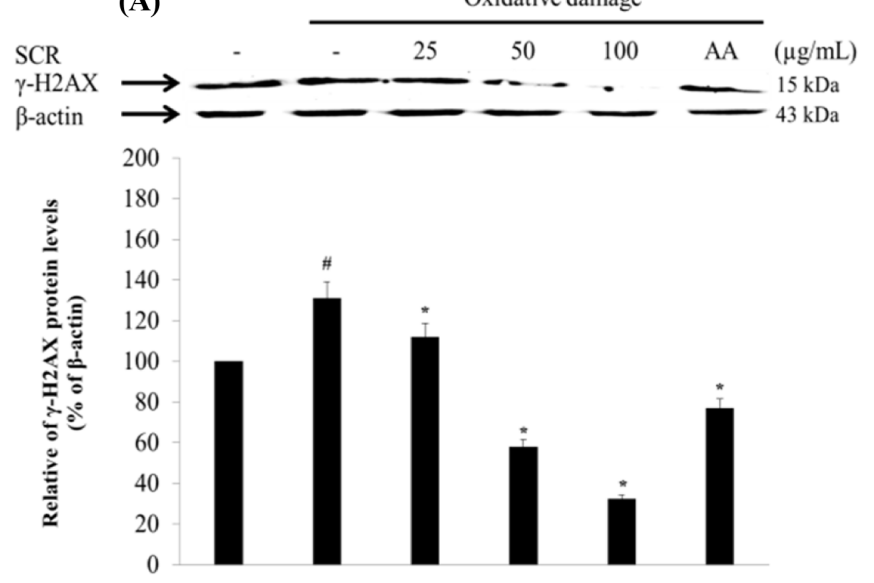

(B)

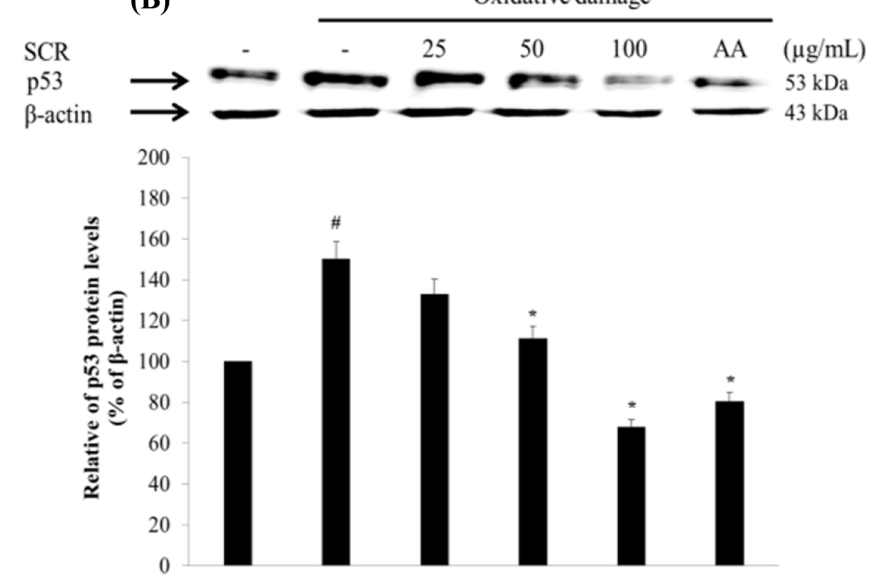

Fig. 7 The $\gamma$-H2AX (A) and p53 (B) expression of Smilax china Root (SCR). NIH 3T3 cells were treated with 25, 50, and $100 \mathrm{mg} / \mathrm{mL}$ Smilax china Root and oxidative for $24 \mathrm{~h}$. Total cell lysates were subjected to Western blotting to measure the expression of $\gamma-\mathrm{H} 2 \mathrm{AX}$ and p53. Relative ratio was quantified after normalization to $\beta$-actin. Each value was then expressed to non-treated (NT) control group, which was set as $100 \%$. Results are expressed as mean $\pm \mathrm{SD}$ for each group from three independent experiments. ${ }^{*}$ Significant compared with NT, $p<0.05 ;{ }^{*} p<0.05$ versus SCR-untreated oxidative stress-treated group. Each band was quantified using the software Un-SCAN-IT gel Version 5.1(Silk Scientific, Inc., Orem, Utah, USA). SCR: Smilax china Root, Oxidative damage: $150 \mu \mathrm{M} \mathrm{FeCl}_{2}+500 \mu \mathrm{M} \mathrm{H}_{2} \mathrm{O}_{2}$, AA: L-ascorbic acid $100 \mu \mathrm{g} / \mathrm{mL}$ 

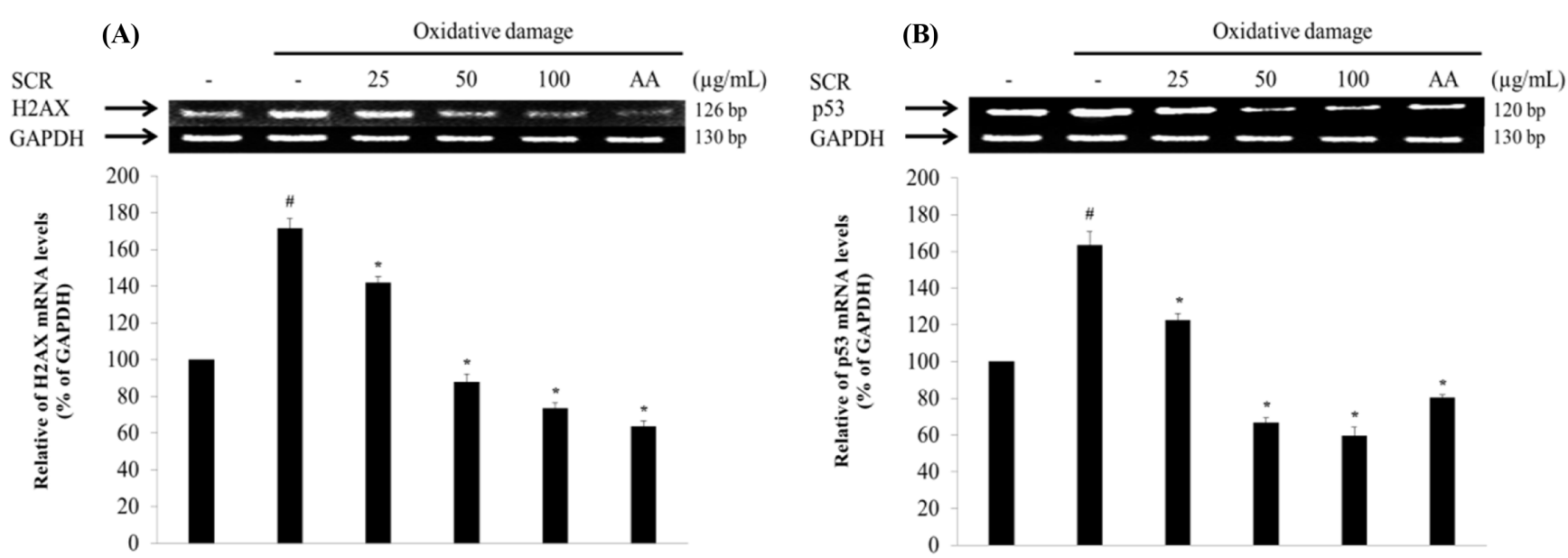

Fig. 8 The H2AX (A) and p53 (B) mRNA levels of Smilax china Root (SCR). NIH 3T3 cells were treated with 25, 50, and $100 \mathrm{mg} / \mathrm{mL}$ Smilax china Root and oxidative stress for $24 \mathrm{~h}$. Total cell lysates were subjected to RT-PCR to measure the mRNA levels of H2AX and p53. Relative ratio was quantified after normalization to GAPDH. Each value was then expressed to non-treated (NT) control group, which was set as $100 \%$. Results are

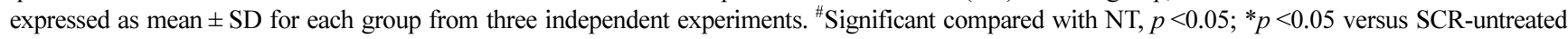
oxidative stress-treated group. Each band was quantified using the software Un-SCAN-IT gel Version 5.1 (Silk Scientific, Inc., Orem, Utah, USA). SCR: Smilax china Root, Oxidative damage: $150 \mu \mathrm{M} \mathrm{FeCl}_{2}+500 \mu \mathrm{M} \mathrm{H}_{2} \mathrm{O}_{2}$, AA: L-ascorbic acid $100 \mu \mathrm{g} / \mathrm{mL}$

화합물을 포함하는 토복령의 항산화 활성은 산화적 스트레스에 대항하는 plasmid DNA 손상 억제 및 세포 수준의 DNA 손상 저해 효과를 나타냈으며, 종양 억제 및 항산화, 항노화 등 다양 한 질병에 대한 경감 및 치료를 목적으로 하는 제약, 화장품, 식품 첨가물로의 활용가치를 확인하였다.

\section{초 록}

최근까지도, 현대사회의 암 발생률은 급격하게 증가하고 있다. 인체 내부에서 내재적 또는 외재적인 요인에 의해 DNA 손상 이 발생되고, 세포는 DNA 손상에 대한 방어기작을 통해 스스 로를 방어한다. 또한, 비정상적인 DNA 생성 및 결손된 DNA 가닥의 복원은 노화, 암, 염증 등 다양한 질병으로부터 기인한 다. 많은 연구자는 이러한 DNA 손상을 억제하기 위하여 적절 한 소재 탐색에 많은 관심을 두고 있으며, 특히 합성화합물의 부작용이 알려지면서, 천연물을 기반으로 한 암 예방적 소재에 대한 연구가 많이 이루어지고 있다. 토복령은 백합과(Liliacese) 에 속하는 청미래덩굴 (Smilax china L.)의 근경이며, 전통적으로 해독과 종기 등의 치료제로 사용되어왔다. 하지만 토복령의 DNA 손상에 대한 억제 효과에 대한 연구는 미흡하다. 본 논문 에서는 토복령의 항산화 효과 및 DNA 손상에 대한 억제 효과 를 확인하고, 식물이 포함하는 phenolic 화합물의 활성과 연관 관계를 확인하고자 하였다. 항산화 효과를 확인하기 위해, DPPH 라디칼 및 $\mathrm{ABTS}$ 라디칼에 대한 소거 활성을 확인하였다. 토복 령 추출물은 $\mathrm{DPPH}$ 및 $\mathrm{ABTS}$ 라디칼을 효과적으로 제거하였으 며, 높은 환원력을 나타냈다. HPLC 분석을 통해 phenolic 화합 물을 정량 및 동정하였으며, 항산화 효과와 phenolic 화합물의 연관 관계를 확인하였다. 또한, $\mathrm{OH}^{-}$라디칼 및 $\mathrm{Fe}^{2+}$ 으로 유발 된 plasmid DNA 손상에 대한 방어 효과를 확인하였다. 세포 수준에서, DNA 손상에 대한 저해 효과는 산화적 스트레스로
유발된 NIH 3T3 세포의 $\gamma-\mathrm{H} 2 \mathrm{AX}$ 및 $\mathrm{p} 53$ 단백질 발현 저해 활성을 확인하였다. 또한, $\mathrm{H} 2 \mathrm{AX}$ 및 p53 mRNA 수준의 저해 활성을 확인하였다. 결론적으로, 토복령 추출물의 phenolic 화합 물의 항산화 효과 및 DNA 손상에 대한 억제 효과를 확인하 였다.

Keywords Antioxidant $\cdot \mathrm{p} 53 \cdot$ Phenolic compounds $\cdot$ Smilax china

감사의 글 이 논문은 중원대학교 교내학술연구비 지원에 의한 것임(과제관 리번호: 2017-024)

\section{References}

1. Kandasamy G, Maity D (2015) Recent advances in superparamagnetic iron oxide nanoparticles (SPIONs) for in vitro and in vivo cancer nanotheranostics. Int J Pharm 496: 191-218

2. Surh YJ (1999) Molecular mechanisms of chemopreventive effects of selected dietary and medicinal phenolic substances. Mutat Res 428: 305327

3. Johnson TM, Yu ZX, Ferrans VJ, Lowenstein RA, Finkel T (1996) Reactive oxygen species are downstream mediators of p53-dependent apoptosis. Proc Natl Acad Sci USA 93: 11848-11852

4. Scharer OD (2003) Chemistry and biology of DNA repair. Angew Chem Int Ed Engl 42: 2946-2974

5. Stadtman ER (2006) Protein oxidation and aging. Free Radic Res 40: $1250-1258$

6. Gilgun-Sherki Y, Rosenbaum Z, Melamed E, Offen D (2002) Antioxidant therapy in acute central nervous system injury: current state. Pharmacol Rev 54: 271-284

7. Kong YJ, Park BK, Oh DH (2001) Antimicrobial activity of Quercus mongolica leaf ethanol extract and organic acids against food-borne microorganisms. Kor J Food Sci Technol 33: 178-183

8. Harold ES, Darrell EA, Evan IF, John AM (2007) A review of the interaction among dietary antioxidants and reactive oxygen species. J 
Nutr Biochem 18: 567-579

9. Hamanaka RB, Chandel NS (2010) Mitochondrial reactive oxygen species regulate cellular signaling and dictate biological outcomes. Trends Biochem Sci 35: 505-513

10. Simon HU, Haj-Yehia A, Levi-Schaffer F (2000) Role of reactive oxygen species (ROS) in apoptosis induction. Apoptosis 5: 415-418

11. Fernandez-Capetillo O, Lee A, Nussenzweig M, Nussenzweig A (2004) H2AX: the histone guardian of the genome. DNA Repair 3: 959-967

12. Stucki M, Clapperton JA, Mohammad D, Yaffe MB, Smerdon SJ, Jackson SP (2005) MDC1 directly binds phosphorylated histone H2AX to regulate cellular responses to DNA doublestrand breaks. Cell 123: $1213-1226$

13. Liu B, Chen Y, St Clair DK (2008) ROS and p53: a versatile partnership. Free Radic Biol Med 44: 1529-1535

14. Polyak K, Xia Y, Zweier JL, Kinzler KW, Vogelstein B (1997) A model for p53-induced apoptosis. Nature 389: 300-305

15. Sablina AA, Budanov AV, Ilyinskaya GV, Agapova LS, Kravchenko JE, Chumakov PM (2005) The antioxidant function of the p53 tumor suppressor. Nat Med 11: 1306-1313

16. Maxwell SR (1995) Prospects for the use of antioxidant therapies. Drugs 49: $345-361$

17. Hwang JY, Lee HS, Han JS (2011) Protective effect of Sasa borealis leaf extract on AAPH-induced oxidative stress in LLC-PK1 cells. J Food Sce Nutr 16: 12-17

18. Warnholtz A, Münzel T (2000) Why do antioxidants fail to provide clinical benefit? Curr Control Trials Cardiovasc Med 1: 38-40

19. Choe SY, Yang KH (1982) Toxicological studies of antioxidants butylated hydroxytoluene (BHT) and butylated hydroxyanisole (BHA). Korean J Food Sci Technol 14: 283-288

20. Lee YS, Joo EJ, Kim NW (2006) Polyphenol contents and antioxidan activity of Lepista nuda. J Korean Soc Food Sci Nutr 35: 1309-1314

21. Lee JC, Kim HR, Kim J, Jang YS (2002) Antioxidant Property of an Ethanol Extract of the Stem of Opuntia ficus-indica var. Saboten. J Agric Food Chem 50: 6490-6496

22. Wei QY, Zhou B, Jun Y, Liu ZL (2006) Synergistic effect of green tea polyphenols with trolox on free radical-ed oxidative DNA damage. Food Chem 96: 90-95

23. Prakash CP, Garima U, Brahma NS, Harikesh B (2007) Antioxidant and free radical-scavenging activities of seeds and agri-wastes of some varieties of soybean (Glycine max). Food Chem 104: 783-790

24. Chen L, Yin H, Lan Z, Ma S, Zhang C, Yang Z, Li P, Lin B (2011) Antihyperuricemic and nephroprotective effects of Smilax china L. J Ethnopharmacol 135: 399-405

25. Shu XS, Gao ZH, Yang XL (2006) Anti-inflammatory and antinociceptive activities of Smilax china L. aqueous extract. J Ethnopharmacol 103: 327-332

26. Cheng DS, Hua XL (2006) Today's research of Smilax china. J Chin Med Tradit Chin Med 29: 90-93

27. Li YL, Gan GP, Zhang HZ, Wu HZ, Li CL, Huang YP, Liu YW, Liu JW (2007) A flavonoid glycoside isolated from Smilax china L. rhizome in vitro anticancer effects on human cancer cell lines. J Ethnopharmacol 113: $115-124$
28. Bondet V, Brand-Williams W, Berset C (1997) Kinetics and mechanisms of antioxidant activity using the DPPH. free radical method. LWT-Food Sci Technol 30: 609-615

29. Van den Berg R, Haenen GR, van den Berg H, Bast AALT (1999) Applicability of an improved Trolox equivalent antioxidant capacity (TEAC) assay for evaluation of antioxidant capacity measurements of mixtures. Food Chem 66: 511-517

30. Oyaizu M (1986) Studies on products of browning reaction: antioxidative activities of products of browning reaction prepared from glucosamine. Jpn J Nutr 44: 307-315

31. Jung Y, Surh Y (2001) Oxidative DNA damage and cytotoxicity unduced by copper-stimulated redox cycling of salsolinol. a neurotoxic tetrahydroisoquinoline alkalooid. Free Radic Biol Med 30: 1407-1417

32. Padayatty SJ, Katz A, Wang Y, Eck P, Kwon O, Lee JH, Chen S, Corpe C, Dutta A, Dutta SK, Levine M (2003) Vitamin C as an antioxidant: evaluation of its role in disease prevention. J Am Coll Nutr 22: 18-35

33. Cabiscol E, Tamarit J, Ros J (2000) Oxidative stress in bacteria and protein damage by reactive oxygen species. Int Microbiol 3: 3-8

34. Ozsoy N, Can A, Yanardag R, Akev N (2008) Antioxidant activity of Smilax excelsa L. leaf extracts. Food Chem 110: 571-583

35. Meir S, Kanner J, Akiri B, Philosoph-Hadas S (1995) Determination and involvement of aqueous reducing compounds in oxidative defense systems of various senescing leaves. J Agric Food Chem 43: 1813-1819

36. Ferreira IC, Baptista P, Vilas-Boas M, Barros L (2007) Free-radical scavenging capacity and reducing power of wild edible mushrooms from northeast Portugal: Individual cap and stipe activity. Food Chem 100: 1511-1516

37. Chanda S, Dave R (2009) In vitro models for antioxidant activity evaluation and some medicinal plants possessing antioxidant properties: An overview. Afr J Microbiol Res 3: 981-996

38. Marnett L (2000) Oxiradicals and DNA damage. Carcinogenesis 21: 361-370

39. Ferreres F, Gomes D, Valentão P, Gonçalves R, Pio R, Chagas EA, Seabra RM, Andrade PB (2009) Improved loquat (Eriobotrya japonica Lindl.) cultivars: Variation of phenolics and antioxidative potential. Food Chem 114: 1019-1027

40. Helleday T, Petermann E, Lundin C, Hodgson B, Sharma RA (2008) DNA repair pathways as targets for cancer therapy. Nat Rev Cancer 8: 193-204

41. Bohgaki T, Bohgaki M, Hakem R (2010) DNA double-strand break signaling and human disorders, Genome Integr 1: 15

42. Shrivastav M, Miller CA, De Haro LP, Durant ST, Chen BP, Chen DJ, Nickoloff JA (2008) DNA-PKcs and ATM co-regulate DNA doublestrand break repair. DNA Repair 8: 920-929

43. Kendra LC, Geoffrey GH (2007) Regulation of the cellular DNA double-strand break response. Biochem Cell Biol 85: 663-674

44. Maréchal A, Zou L (2013) DNA damage sensing by the ATM and ATR kinases. Cold Spring Harb Perspect Biol. doi: 10.1101/cshperspect. a012716

45. Harper JW, Elledge SJ (2007) The DNA damage response: ten years after. Mol Cell 28: 739-745 